\title{
Lamella Silicon Solar Cell under Both Temperature and Magnetic Field: Width Optimum Determination
}

\author{
Dibor Faye, Sega Gueye, Mor Ndiaye, Mamadou Lamine Ba, Ibrahima Diatta, Youssou Traore, \\ Masse Samba Diop, Gora Diop, Amadou Diao, Gregoire Sissoko
}

Laboratory of Semiconductors and Solar Energy, Physics Department, Faculty of Science and Technology, University Cheikh Anta Diop, Dakar, Senegal

Email: gsissoko@yahoo.com

How to cite this paper: Faye, D., Gueye, S., Ndiaye, M., Ba, M.L., Diatta, I., Traore, Y., Diop, M.S., Diop, G., Diao, A. and Sissoko, G. (2020) Lamella Silicon Solar Cell under Both Temperature and Magnetic Field: Width Optimum Determination. Journal of Electromagnetic Analysis and Applications, 12, 43-55.

https://doi.org/10.4236/jemaa.2020.124005

Received: April 13, 2020

Accepted: April 27, 2020

Published: April 30, 2020

Copyright $\odot 2020$ by author(s) and Scientific Research Publishing Inc. This work is licensed under the Creative Commons Attribution International License (CC BY 4.0).

http://creativecommons.org/licenses/by/4.0/

\begin{abstract}
This work deals with determining the optimum thickness of the lamella wafer of silicon solar cell. The (p) base region makes up the bulk of the thickness of the wafer. This thickness has always been a factor limiting the performance of the solar cell, as it produces the maximum amount of electrical charges, contributing to the photocurrent. Determining the thickness of the wafer cannot be only mechanical. It takes into account the internal physical mechanisms of generation-diffusion-recombination of excess minority carriers. They are also influenced by external factors such as temperature and magnetic field. Under these conditions, magneto transport equation is required to be applied on excess minority carrier in lamella base silicon solar cell. It yields maximum diffusion coefficient which result on Lorentz law and Umklapp process. Then from photocurrent, back surface recombination velocity expressions are derived, both maximum diffusion coefficient and thickness dependent. The plot of the back surface recombination calibration curves as function of lamella width, leads to its maximum values, trough intercept points. Lamella optimum width is then obtained, both temperature and magnetic field dependent and expressed in relationships to show the required base thickness in the elaboration process.
\end{abstract}

\section{Keywords}

Silicon Vertical Junction, Back Surface Recombination Velocity, Magnetic Field, Temperature, Lamella Width

\section{Introduction}

The manufacturing architecture silicon solar cells evolves to improve photovol- 
taic conversion efficiency, at lower cost [1] [2] [3] [4].

Many architectures have been achieved, such as, monofacial solar cells (front or rear illumination), bifacial (simultaneous illumination both sides), vertical junction (series or parallel), in order to absorb maximum incident flow and generate excess minority carriers allowing to be collected, before undergoing recombination (in the bulk or on surfaces) [5] [6].

Lifetime $(\tau)$ [7] [8] [9], diffusion coefficient (D) [10], diffusion length (L) [11] [12] [13] [14] [15] and surface recombination velocity [16] [17] [18] [19] [20], at junction (Sf) [21]-[26], on back (Sb) [27] [28] [29] [30], at grain boundaries (Sg) [31] are intrinsic parameters in development of silicon material and of solar cells manufacturing [32].

Quality control of manufacturing solar cell is done by measuring these parameters, under light optical excitation [33], or electric [34]. The solar cell can be placed under different regimes, i.e. static [35] [36], transient dynamics [37] [38] [39] [40] [41] or frequency [42] [43] [44]. The operating points can be short circuit or open circuit, or any other point of the illuminated (or dark) current-voltage characteristic [45] [46].

However solar cell base thickness $(\mathrm{H})$ is a geometric parameter to consider, compared to minority carriers diffusion length, to ensure a high probability collection of photocreated carriers [47] [48] [49] [50] [51].

The vertical multi-junction silicon solar cells (VMJ) [52] [53] [54] [55], use materials having charge carriers with short diffusion length, but its architecture gives the advantage of excess minority carriers to be collected, without traveling great distances. Indeed the low thickness base can be combined with two emitter allowing the collection of minority carrier (PVMJ) [56] [57], or by existence a rear field (junction $\mathrm{p} / \mathrm{p}^{+}$) who drives them back, thus reducing the distance to be covered (SVMJ) [58]. This rear field induces a recombination velocity minority charge carriers ( $\mathrm{Sb}$ ) that characterize the back surface of solar cell (BSF or ohmic contact) and then gives the rate of charge carrier loss [27] [28] [29] [30] [48] [49].

Our study is interested in the lamella thickness determination, through the new expression of recombination velocity at the back side. This allows extending the life of minority charge carriers in lamella and promotes the solar cell performance, under the effect of both external magnetic field and temperature.

\section{Theory}

Figure 1 shows the structure of vertical multi-junction silicon solar cells connected in series [52] [53] [58]. It is composed a succession of junctions ( $\left.\mathbf{n}^{+}-\mathbf{p}-\mathbf{p}^{+}\right)$ joined together with metallic ( $\mathrm{Al})$ contacts. Incidental illumination occurs parallel to junctions i.e. space charge region plane (SCR) [59] [60]. The elaboration of junction $\left(\mathrm{p}-\mathrm{p}^{+}\right)$produces the back field effect, that induces excess minority carriers back surface recombination velocity $(\mathrm{Sb})$, that straugths back them towards the junction (SCR) and thus avoids their recombination [28].

Figure 2 shows a section of vertical junction silicon solar cell unit, with the different regions (emitter, junction, base, rear field area). The axis $(\mathbf{O x})$, to origin 


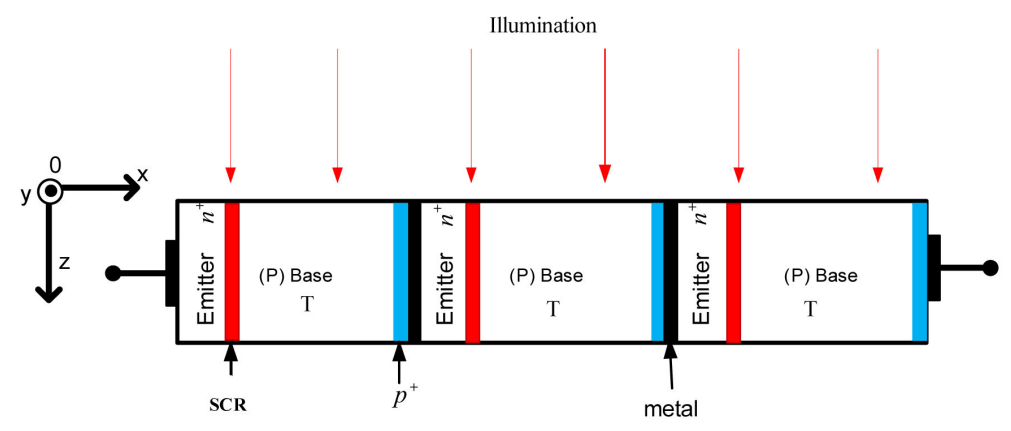

Figure 1. Vertical multi junction solar cells connected in series.

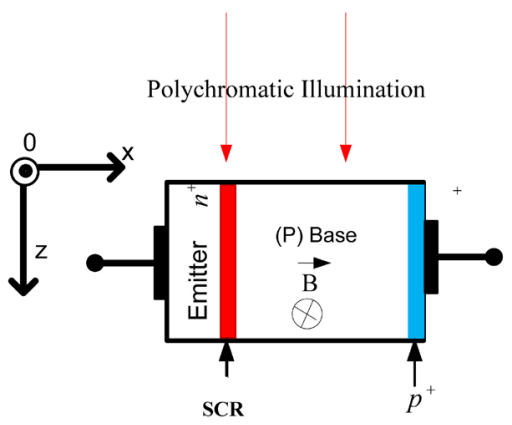

Figure 2. Unit $\left(\mathrm{n}^{+}-\mathrm{p}-\mathrm{p}^{+}\right)$cell under illumination and under the effect of an external magnetic field.

from the junction (front side of the base). The base is a thickness $H$ lamella, seat of rear electric field $\left(\mathrm{p}-\mathrm{p}^{+}\right)$. The $\mathrm{Oz}$ axis, gives the illumination sense and depth $Z$, place of creation of monority charge carriers in solar cell. The magnetic field which plays a deflecting role (Lorentz law) on minority charge carriers, is perpendicular to the plane $(\mathbf{O}, \mathbf{x}, \mathbf{z})$, i.e., along Oy axis.

\subsection{Magneto Transport Equation}

Excess minority carrier's density $\delta(x)$, generated on the abscissa $x$ and at depth $z$, in the base of solar cell in steady regime, undergo the law magneto-transport, presented through the following continuity equation [61]:

$$
\frac{\partial^{2} \delta(x, z, B, T)}{\partial x^{2}}-\frac{\delta(x, z, B, T)}{L^{* 2}(B, T)}+\frac{G(z)}{D^{*}(B, T)}=0
$$

Diffusion length $L^{*}(B, T)$ minority carriers in the base of solar cell under magnetic field $\mathrm{B}$ at temperature $T$ is:

$$
L^{*}(B, T)=\sqrt{\tau \cdot D^{*}(B, T)}
$$

$D^{*}(B, T)$ The diffusion coefficient of minority carriers in the base under influence of temperature $T$ and the magnetic field $B$ applied is given by the relation [21] [62]:

$$
D^{*}(B, T)=\frac{D_{0}(T)}{\left[1+(\mu(T) \times B)^{2}\right]}
$$


where $D_{0}(T)$ is the diffusion coefficient versus temperature $T$, in the solar cell without magnetic field. It is given by the Einstein-Smoluchowski [63] [64]:

$$
D_{0}(T)=\mu(T) \times \frac{k_{b} \times T}{q}
$$

With $\mu(T)$ is the minority carriers mobility temperature dependent in the base and expresses as [38]:

$$
\mu(T)=1.43 \times 10^{9} T^{-2.42} \mathrm{~cm}^{2} \cdot \mathrm{V}^{-1} \cdot \mathrm{s}^{-1}
$$

$q$ is the electron elementary charge.

$k_{b}$ is Boltzmann's constant given as: $k_{b}=1.38 \times 10^{-23} \mathrm{~m}^{2} \cdot \mathrm{kg} \cdot \mathrm{s}^{-2} \cdot \mathrm{K}^{-1}$.

The generation rate of minority charge carriers generated at depth $z$ in the base is modeled and expressed by the following relation [65]:

$$
G(z)=\sum_{i=1}^{3} a_{i} \exp \left(-b_{i} z\right)
$$

The coefficients $a_{i}$ and $b_{i}$ are obtained from the tabulated values of the radiation.

\subsection{Solution}

The solution of magneto transport equation is given by the following expression of the minority charge carrier density as:

$$
\begin{aligned}
\delta(x, z, B, T)= & A_{1} \cosh \left(\frac{x}{L^{*}(B, T)}\right)+A_{2} \sinh \left(\frac{x}{L^{*}(B, T)}\right) \\
& +\sum_{i=1}^{3} K_{i}(B, T) \cdot \exp \left(-b_{i} z\right)
\end{aligned}
$$

With

$$
K_{i}(B, T)=\frac{a_{i} \times L^{* 2}(B, T)}{D^{*}(B, T)}
$$

\subsection{Boundary Conditions}

The previous relationship is fully defined, by determining the coefficients $A_{1}$ and $A_{2}$, using base boundary conditions, what are junction (SCR) and back side:

1) At the junction $\left(\mathrm{n}^{+} / \mathrm{p}\right), x=0$, it is given by [66]

$$
\left.\frac{\partial \delta(x, z, B, T)}{\partial x}\right|_{x=0}=\left.\frac{S f}{D^{*}(B, T)} \delta(x, z, B, T)\right|_{x=0}
$$

2) At back surface $\left(\mathrm{p} / \mathrm{p}^{+}\right), x=H$, it is given by [28] [67]:

$$
\left.\frac{\partial \delta(x, z, B, T)}{\partial x}\right|_{x=H}=-\left.\frac{S b}{D^{*}(B, T)} \delta(x, z, B, T)\right|_{x=H}
$$

$S f$ is excess minority carrier junction recombination velocity. It has two components, one defines the operating point, thus, it is imposed by the external load resistor, and the other is the intrinsic recombination velocity, which is related to the solar cell shunt resistance in electric equivalent model [66] [68]. 
$S b$ is back surface recombination velocity $(x=H)$, where there is an electric field $\left(\mathrm{p} / \mathrm{p}^{+}\right)$, allowing repel the minority charge carriers towards junction $\left(\mathrm{n}^{+} / \mathrm{p}\right)$ and avoid their back side recombination [28]. Thus the collection rate of minority carries participating in the photocurrent increases.

\section{Results and Discussions}

\subsection{Photocurrent Density}

The excess minority carriers collected through junction give photocurrent density Jph obtained from the following Fick relation:

$$
J_{p h}(S f, H, z, B, T, S b)=\left.q \cdot D \cdot \frac{\partial \delta(S f, H, z, B, T, S b)}{\partial x}\right|_{x=0}
$$

\subsection{Back Surface Recombination Velocity}

Solving Equation (12), leads to two expressions of excess minority carrierback surface recombination velocity in the base as, $S b_{1}$ and $S b_{2}$ :

$$
\begin{gathered}
\left.\frac{\partial J_{p h}(S f, H, z, B, T, S b)}{\partial S f}\right|_{S f \geq 10^{5}}=0 \\
S b_{1}(H, B, T)=-\frac{D(B, T) \cdot \operatorname{sh}\left(\frac{H}{L(B, T)}\right)}{L(B, T) \cdot\left(\operatorname{ch}\left(\frac{H}{L(B, T)}\right)-1\right)} \\
S b_{2}(H, B, T)=-\frac{D(B, T)}{L(B, T)} \cdot \operatorname{th}\left(\frac{H}{L(B, T)}\right)
\end{gathered}
$$

The maximum values of diffusion coefficient as a function of optimum temperature for different values of magnetic field were determined by comparisons of two different methods according to relationship [69]:

$$
D_{\max }(B)=2.1 \times 10^{5}\left[T_{\text {opt }}(B)\right]^{-1.58}
$$

Other authors, using the same approach, proposed in 3D study or in frequency modulation the following expressions:

- Optimum temperature depending magnetic field [70] is given as:

$$
T_{\text {opt }}(B)=\sqrt[4.85]{2.56\left[1.43 \times 10^{9}\right]^{2} B^{2}}
$$

- Maximum diffusion coefficient as a function of cyclotronic frequency for different values magnetic field [71]

$$
D_{\max }(\omega, B)=1.717 \times 10^{6}\left[T_{\text {opt }}(\omega, B)\right]^{-2.065}
$$

These relationships show that the choice of values of parameters like the temperature, the magnetic field and the frequency must obey certain conditions for obtaining solar cell good performance. 
In Figure 3, we represent the profiles of two back surface recombination velocity of excess minority carriers depending on thickness base solar cell for different diffusion coefficient maximum values as a function of optimum temperature and magnetic field.

For each value of maximum diffusion coefficient, the optimum thickness $H_{o p}$ of base is determined by projection on abscissa-axis of the intercept point of $S b_{1}$ and $S b_{2}$ curves. Thus the different values are presented in Table 1.

Figure 4 shows the lamella optimum width $\left(H_{o p}\right)$ as function of maximum diffusion coefficient.

We note that lamella optimum thickness increases linearly according to maximum diffusion coefficient. Considering the best fit, we can write the following relation:

$$
H_{o p}=a \cdot D_{\max }+b
$$

The constants $a$ and $b$ are respectively the slope and the ordinate at origin of line. We get the following equation:

$$
H_{\text {op }}=0.00012 D_{\max }+0.01430
$$

Figure 5 shows the lamella optimum thickness $\left(H_{o p}\right)$ versus magnetic field.

The best fit gives the following modeling equation for mean curve in the form:

$$
H_{\text {op }}(B)=-3.4 \times 10^{3} B^{3}+9.7 \times 10^{3} B^{2}-10 B+0.018
$$

The base optimum thickness decreases depending on the applied magnetic field. Indeed, when the magnetic field increases, mobility and diffusion of minority carriers decrease with the increase in the intensity of Lorentz force slowing down the movement of charge carriers [21]. There is thus a decrease in the diffusion coefficient resulting in the decrease of base optimum thickness.

Figure 6 shows the lamella optimum thickness $H_{o p}$ as a function optimum temperature.

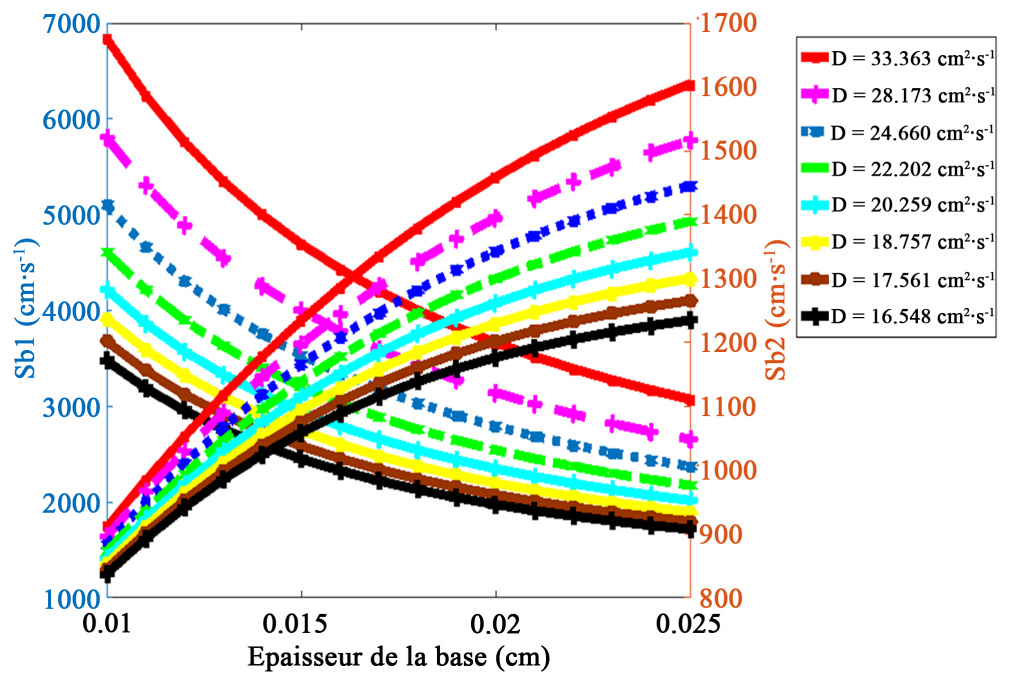

Figure 3. Back surface recombination velocity of excess minority carries versus solar cell base thickness for different maximum diffusion coefficient values. 


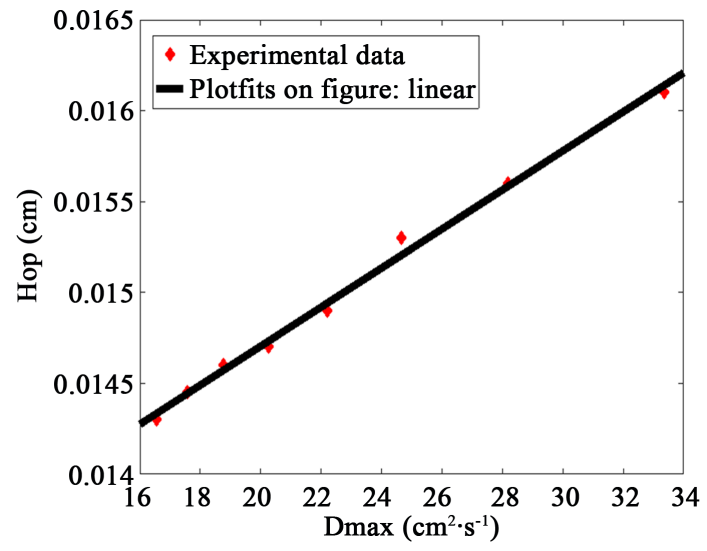

Figure 4. Profile lamella optimum thickness $H_{o p}$ versus maximum diffusion coefficient.

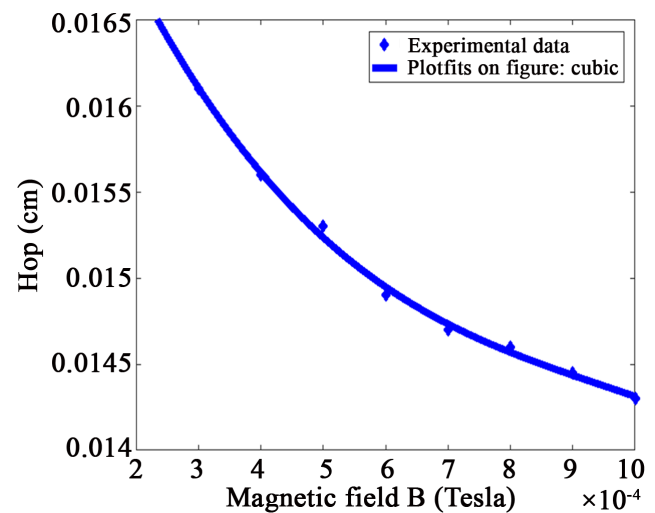

Figure 5. Profile of lamella optimum thickness $H_{o p}$ versus magnetic field.

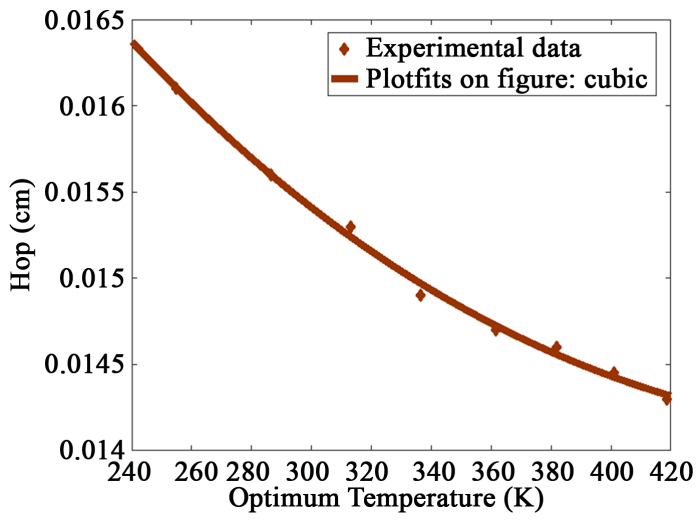

Figure 6. Profile of lamella optimum thickness $\left(H_{o p}\right)$ versus optimum temperature.

Table 1. Base optimum thickness $\left(H_{o p}\right)$ for different magnetic field $B$ and optimum temperature values.

\begin{tabular}{ccccccccc}
\hline$B$ (Tesla) & 0.0003 & 0.0004 & 0.0005 & 0.0006 & 0.0007 & 0.0008 & 0.0009 & 0.001 \\
\hline $\begin{array}{c}\text { Optimum } \\
\text { temperature (Kelvin) }\end{array}$ & 254.7 & 286.6 & 313 & 336.5 & 361.4 & 381.9 & 401.0 & 418.8 \\
$D_{\max }\left(\mathrm{cm}^{2} / \mathrm{s}\right)$ & 33.368 & 28.173 & 24.66 & 22.202 & 20.259 & 18.757 & 17.561 & 16.548 \\
$H_{o p}(\mathrm{~cm})$ & 0.0161 & 0.0156 & 0.0153 & 0.0149 & 0.0147 & 0.0146 & 0.01445 & 0.0143 \\
\hline
\end{tabular}


The average curve modeling equation is in the form:

$$
H_{\text {op }}(T)=-3.2 \times 10^{-11} T^{3}+7 \times 10^{-8} T^{2}-4.5 \times 10^{-5} T+0.024
$$

The lamella optimum thickness $H_{o p}$ decreases according to optimum temperature. Indeed, when the temperature is high, the phonons are excited and material resistivity decreases with Umklapp processes [72] [73] which limit thermal conductivity. Thermal agitation reduces excess minority carrier's mobility and obviously diffusion coefficient, that explains the decrease in lamella optimal thickness according to the modeling relation found.

\section{Conclusions}

This thickness optimization technique plays an important role in the case of vertical solar cell junction, which uses low quality materials, whose minority carriers have low diffusion lengths. It makes the back surface recombination velocity at $\left(\mathrm{p}-\mathrm{p}^{+}\right)$more efficient by a judicious choice of lamella thickness.

That's why, the two expressions of back surface recombination of excess minority carriers are required to determine the lamella optimum thickness for different values of diffusion coefficient as a function of optimum temperature for different magnetic field values. So the different relationships found justify the choice of the lamella optimal thickness either as a function of temperature or magnetic field. Consequently these results can be used as a tool for selecting lamella elaboration process.

\section{Conflicts of Interest}

The authors declare no conflicts of interest regarding the publication of this paper.

\section{References}

[1] Rodot, L.Q.N.M. (1992) Solar Cells with 15.6\% Efficiency on Multicrystalline Silicon, Using Impurity Gettering Back Surface Field and Emitter Passivation. International Journal of Solar Energy, 11, 273-279. https://doi.org/10.1080/01425919208909745

[2] Luque, A., Ruiz, J.M., Cuevas, A., Eguren, J. and Agost, M.G. (1997) Double Side Solar Cells to Improve Static Concentrator. Proceedings of the 1st European Photovoltaic Solar Energy Conference, Luxembourg, 269-277. https://doi.org/10.1007/978-94-009-9840-7_25

[3] Yadav, P., Pandey, K., Tripathi, B., Kumar, C.M., Srivastava, S.K., Singh, P.K. and Kumar, M. (2015) An Effective Way to Analyze the Performance Limiting Parameters of a Poly-Crystalline Silicon Solar Cell Fabricated in the Production Line. Solar Energy, 122, 1-10. https://doi.org/10.1016/j.solener.2015.08.005

[4] Ohtsuka, H., Sakamoto, M., Tsutsui, K. and Yazawa, Y. (2000) Bifacial Silicon Solar Cells with 21.3\% Front Efficiency and 19.8\% Rear Efficiency. Progress in Photovoltaics. Research and Applications, 8, 385-390. https://doi.org/10.1002/1099-159X(200007/08)8:4<385::AID-PIP340>3.0.CO;2-B

[5] Green, M.A. (1995) Silicon Solar Cells Advanced Principles \& Practice. Bridge Printer Pty. Ltd., Clayton North, 29-35. 
[6] Meusel, M., Benssch, W., Berdunde, T., Kern, R., Khorenko, V., Kostler, W., Laroche, G., Torunski, T., Zimmermann, W., Strobl, G., Guter, W., Hermle, M., Hoheisel, R., Siefer, G., Welser, E., Dimroth, F., Bett, A.W., Geens, W., Baur, C., Taylor, S. and Hey, G. (2007) Development and Production of European III-V Multijunction Solar Cells. Proceeding of the 22nd European Photovoltaic Solar Energy Conference, 16-51.

[7] Misiakos, K., Wang, C.H., Neugroschel, A. and Lindholm, F.A. (1990) Simultaneous Extraction of Minority-Carrier Parameters in Crystalline Semiconductors by Lateral Photocurrent. Journal of Applied Physics, 67, 321-333.

https://doi.org/10.1063/1.345256

[8] Sinton, R.A. and Cuevas, A. (1996) Contactless Determination of Current-Voltage Characteristics and Minority-Carrier Lifetimes in Semiconductors from QuasiSteady-State Photoconductance Data. Applied Physics Letters, 69, 2510-2512. https://doi.org/10.1063/1.117723

[9] Basu, P.K. and Singh, S.N. (1994) On the Determination of Minority Carrier Diffusion Length in the Base Region of $\mathrm{n}^{+}-\mathrm{p}^{-} \mathrm{p}^{+}$Silicon Solar Cells Using Photoresponse Methods. Solar Energy Materials and Solar Cells, 33, 317-329. https://doi.org/10.1016/0927-0248(94)90234-8

[10] Rosling, M., Bleichner, H., Mundqvist, M. and Nordlander, E. (1992) A Novel Technique for the Simultaneous Measurement of Ambipolar Carrier Lifetime and Diffusion Coefficient in Silicon. Solid-State Electronics, 35, 1223-1227. https://doi.org/10.1016/0038-1101(92)90153-4

[11] Stokes, E.D. and Chu, T.L. (1977) Diffusion Lengths in Solar Cells from Short-Circuit Current Measurements. Applied Physics Letters, 30, 425-426. https://doi.org/10.1063/1.89433

[12] Donolato, C. (1994) Reciprocity Theorem for Charge Collection by a Surface with Finite Collection Velocity: Application to Grain Boundaries. Journal of Applied Physics, 76, 959-966. https://doi.org/10.1063/1.357774

[13] Reynolds, J.H. and Meulenberg, A. (1974) Measurement of Diffusion Length in Solar Cells. Journal of Applied Physics, 45, 2582-2592. https://doi.org/10.1063/1.1663633

[14] Alam, M.K. and Yeow, Y.T. (1981) Evaluation of the Surface Photovoltage Method of Minority-Carrier Diffusion-Length Measurement. Solid-State Electronics, 24, 1117-1119. https://doi.org/10.1016/0038-1101(81)90179-9

[15] Sharma, S.K., Singh, S.N., Chakravarty, B.C. and Das, B.K. (1986) Determination of Minority-Carrier Diffusion Length in a p-Silicon Wafer by Photocurrent Generation Method. Journal of Applied Physics 60, 3550-3552.

https://doi.org/10.1063/1.337610

[16] Mazhari, B. and Morkoç, H. (1993) Surface Recombination Velocity by Chemical Treatment. Journal of Applied Physics, 73, 7509-7514. https://doi.org/10.1063/1.353998

[17] De Visschere, P. (1986) Comment on G. J. Rees Surface Recombination Velocity-A Useful Concept? Solid-State Electronics, 29, 1161-1165. https://doi.org/10.1016/0038-1101(86)90059-6

[18] Takahashi, Y., Kondo, H., Yamazaki, T., Uraoka, Y. and Fuyuki, T. (2007) Precise Analysis of Surface Recombination Velocity in Crystalline Silicon Solar Cells Using Electroluminescence. Japanese Journal of Applied Physics, 46, 1149-1151. https://doi.org/10.1143/JJAP.46.L1149

[19] Verlinden, P. and Van De Wiele, F. (1983) Determination of Diffusion Length and 
Surface Recombination Velocity in Interdigitated Back Conctact (IBC) Solar Cells. Solid-State Electronics, 26, 1089-1094. https://doi.org/10.1016/0038-1101(83)90007-2

[20] Diasse, O., Diao, A., Wade, M., Diouf, M.S., Diatta, I., Mane, R., Traore, Y. and Sissoko, G. (2018) Back Surface Recombination Velocity Modeling in White Biased Silicon Solar Cell under Steady State. World Journal of Condensed Matter Physics, 9, 189-201. https://doi.org/10.4236/jmp.2018.92012

[21] Diao, A., Wade, M., Thiame, M. and Sissoko, G. (2017) Bifacial Silicon Solar Cell Steady Photoconductivity under Constant Magnetic Field and Junction Recombination Velocity Effects. Journal of Modern Physics, 8, 2200-2208. https://doi.org/10.4236/jmp.2017.814135

[22] Ba, F., Seibou, B., Wade, M., Diouf, M.S., Ly, B. And Sissoko, G. (2016) Equivalent Electric Model of the Junction Recombination Velocity limiting the Open Circuit of a Vertical Parallel Junction Solar Cell under Frequency Modulation. IPASJ International Journal of Electronics \& Communication, 4, 1-11.

[23] Diouf, M.S., Sahin, G., Thiam, A., Ngom, M.I., Faye, K., Gaye, D. and Sissoko, G. (2015) Determination of the Junction Surface Recombination Velocity Limiting the Open Circuit (Sfoc) for a Bifacial Silicon Solar Cell under External Electric Field. International Journal of Innovative Science, Engineering \& Technology, 2, 931-938. http://www.ijiset.com

[24] Ly, I., Ndiaye, M., Wade, M., Thiam, N., Gueye, S. and Sissoko, G. (2013) Concept of Recombination Velocity Sfcc at the Junction of a Bifacial Silicon Solar Cell, in Steady State, Initiating the Short-Circuit Condition. Research Journal of Applied Sciences, Engineering and Technology, 5, 203-208. https://doi.org/10.19026/rjaset.5.5105

[25] Bocande, Y.L.B., Correa, A., Gaye, I., Sow, M.L. and Sissoko, G. (1994) Bulk and Surfaces Parameters Determination in High Efficiency Si Solar Cells. Renewable Energy, 5, 1698-1700.

[26] El Hadji, N., Sahin, G., Thiam, A., Dieng, M., Ly Diallo, H., Ndiaye, M. and Sissoko, G. (2015) Study of the Intrinsic Recombination Velocity at the Junction of Silicon Solar under Frequency Modulation and Irradiation. Journal of Applied Mathematics and Physics, 3, 1522-1535. http://www.scirp.org/journal/jamp https://doi.org/10.4236/jamp.2015.311177

[27] Rose, B.H. and Weaver, H.T. (1983) Determination of Effective Surface Recombination Velocity and Minority Carrier Lifetime in High-Efficiency Si Solar Cells. Journal of Applied Physics 54, 238-247. https://doi.org/10.1063/1.331693

[28] Fossum, J.G. (1977) Physical Operation of Back-Surface-Field Silicon Solar Cells. IEEE Transactions on Electron Devices, 2, 322-325.

https://doi.org/10.1109/T-ED.1977.18735

[29] Sissoko, G., Sivoththananm, S., Rodot, M. and Mialhe, P. (1992) Constant Illumnation-Induced Open Circuit Voltage Decay (CIOCV) Method, as Applied to High Efficiency Si Solar Cells for Bulk and Back Surface Characterization. 11 th European Photovoltaic Solar Energy Conference and Exhibition, Montreux, 352-354.

[30] Diallo, H.L., Maïga, A.S., Werene, A. and Sissoko, G. (2008) New Approach of Both Junction and Back Surface Recombination Velocities in a 3D Modeling Study of a Polycrystalline Silicon Solar Cell. The European Physical Journal Applied Physics, 42, 203-211. https://doi.org/10.1051/epjap:2008085

[31] Dugas, J. (1994) 3D Modelling of a Reverse Cell Made with Improved Multicrystalline Silicon Wafers. Solar Energy Materials and Solar Cells, 32, 71-88. 
https://doi.org/10.1016/0927-0248(94)90257-7

[32] Gupta, S., Ahmed, F. and Garg, S. (1988) A Method for the Determination of the Material Parameters, D, $\mathrm{L}_{0}$, S and from Measured A.C. Short-Circuit Photocurrent. Solar Cells, 25, 61-72. https://doi.org/10.1016/0379-6787(88)90058-0

[33] Flohr, Th. and Helbig, R. (1989) Determination of Minority-Carrier Lifetime and Surface Recombination Velocity by Optical-Beam-Induced-Current Measurements at Different Light Wavelengths. Journal of Applied Physics, 66, 3060-3065. https://doi.org/10.1063/1.344161

[34] Zondervan, A., Verhoef, L.A. and Lindholm, F.A. (1988) Measurement Circuits for Silicon-Diode and Solar-Cell Lifetime and Surface Recombination Velocity by Electrical Short-Circuit Current Decay. IEEE Transactions on Electron Devices, 35, 85-88. https://doi.org/10.1109/16.2419

[35] Sissoko, G., Nanéma, E., Ndiaye, A.L., Bocandé, Y.L.B. and Adj, M. (1996) Minority Carrier Diffusion Length Measurement in Silicon Solar Cell under Constant White Bias Light. Renewable Energy, 3, 1594-1597.

[36] Luque, A., Ruiz, J.M., Cuevas, A., Eguren, J. and Agost, M.G. (1997) Double Side Solar Cells to Improve Static Concentrator. Photovoltaic Solar Energy Conference, Luxembourg, 269-277. https://doi.org/10.1007/978-94-009-9840-7_25

[37] Dieye, M., Mbodji, S., Zoungrana, M., Zerbo, I., Dieng, B. and Sissoko, G. (2015) A 3D Modelling of Solar Cell's Electric Power under Real Operating Point. World Journal of Condensed Matter Physics, 5, 275-283.

http://www.scirp.org/journal/wjcmp https://doi.org/10.4236/wjcmp.2015.54028

[38] Kunst, M., Muller, G., Schmidt, R. and Wetzel, H. (1988) Surface and Volume Decay Processes in Semiconductors Studied by Contactless Transient Photoconductivity Measurements. Applied Physics, 46, 77-85. https://doi.org/10.1007/BF00615912

[39] Lindholm, F.A., Liou, J.J., Neugroschel, A., and Jung, T.W. (1987) Determination of Lifetime and Surface Recombination Velocity of p-n Junction Solar Cells and Diodes by Observing Transients. IEEE Transactions on Electron Devices, 34, 277-283. https://doi.org/10.1109/T-ED.1987.22919

[40] Barro, F.I., Maiga, A.S., Wereme, A. and Sissoko, G. (2010) Determination of Recombination Parameters in the Base of a Bifacial Silicon Solar Cell under Constant Multispectral Light. Physical and Chemical News, 56, 76-84.

[41] Jung, T.-W., Lindholm, F.A. and Neugroschel, A. (1984) Unifying View of Transient Responses for Determining Lifetime and Surface Recombination Velocity in Silicon Diodes and Back-Surface-Field Solar Cells, with Application to Experimental Short-Circuit-Current Decay. IEEE Transactions on Electron Devices, 31, 588-595. https://doi.org/10.1109/T-ED.1984.21573

[42] Belmonte, G.G., Boix, P.P., Bisquert, J., Sessolo, M. and Bolink, H.J. (2010) Simultaneous Determination of Carrier Lifetime and Electron Density-of-States in P3HT: PCBM Organic Solar Cells under Illumination by Impedance Spectroscopy. Solar Energy Materials \& Solar Cells, 94, 366-375. https://doi.org/10.1016/j.solmat.2009.10.015

[43] Wang, C.H. and Neugroschel, A. (1987) Minority-Carrier Lifetime and Surface Recombination Velocity Measurement by Frequency-Domain Photpluminescence. IEEE Transaction on Electron Devices, 38, 2169-2180. https://doi.org/10.1109/16.83745

[44] Honma, N., Munakata, C. and Shimizu, H. (1988) Calibration of Minority Carrier Lifetimes Measured with an Ac Photovoltaic Method. Japanese Journal of Applied 
Physics, 27, 1322-1326. https://doi.org/10.1143/JJAP.27.1322

[45] Dione, B., Sow, O., Wade, M., Ibrahima, L.Y., Mbodji, S. and Sissoko, G. (2016) Experimental Processus for Acquisition Automatic Features of I-V Properties and Temperature of the Solar Panel by Changing the Operating Point. Circuits and Systems, 7, 3984-4000. http://www.scirp.org/journal/cs https://doi.org/10.4236/cs.2016.711330

[46] Sissoko, G. and Mbodji, S. (2011) A Method to Determine the Solar Cell Resistances from Single I-V Characteristic Curve Considering the Junction Recombination Velocity (Sf). International Journal of Pure and Applied Sciences and Technology, 6, 103-114.

[47] Lago-Aurrekoetxea, R.M., del Can Izo, C., Pou, I. and Luque, A. (2001) Fabrication Process for Thin Silicon Solar Cells. 17 th European PVSEC, Munich, 1519-1522.

[48] Schneider, A., Gerhards, C., Huster, F., Neu, W., Spiegel, M., Fath, P., Bucher, E., Young, R.J.S., Prince, A.G., Raby, J.A. and Carollal, A.F. (2001) BSF for Thin Screen-Printed Multicrystalline Si Solar Cells. 17th European PVSEC, Munich, 17681771.

[49] Bertrand, D., Manuel, S., Pirot, M., Kaminski-Cachopo, A. and Veschetti, Y. (2017) Modelling of Edge Losses in Al-BSF Silicon Solar Cells. IEEE Journal of Photovoltaics, 7, 78-84. https://doi.org/10.1109/JPHOTOV.2016.2618603

[50] Honma, N. and Munakata, C. (1987) Sample Thickness Dependence of Minority Carrier Lifetimes Measured Using an Ac Photovoltaic Method. Japanese Journal of Applied Physics, 26, 2033-2036. https://doi.org/10.1143/JJAP.26.2033

[51] Schinke, C., Hinken, D., Bothe, K., Ulzhöfer, C., Milsted, A., Schmidt, J. and Brendel, R. (2011) Determination of the Collection Diffusion Length by Electroluminescence Imaging. Energy Procedia, 8, 147-152. https://doi.org/10.1016/j.egypro.2011.06.116

[52] Wise, J.F. (1970) Vertical Junction Hardened Solar Cell. U.S. Patent 3, 690-953.

[53] Gover, A. and Stella, P. (1974) Vertical Multijunction Solar-Cell One-Dimensional Analysis. IEEE Transactions on Electron Devices, ED-21, 351-356. https://doi.org/10.1109/T-ED.1974.17927

[54] Mazhari, B. and Morkoç, H. (1993) Theoretical Study of a Parallel Vertical Multi-Junction Silicon. Journal of Applied Physics, 73, 7509-7514. https://doi.org/10.1063/1.353998

[55] Dione, M.M., Ly Diallo, H., Wade, M., Ly, I., Thiame, M., Toure, F., Gueye Camara, A., Dieme, N., Nouhou Bako, Z., Mbodji, S., Barro, F.I. and Sissoko, G. (2010) Determination of the Shunt and Series Resistances of a Vertical Multijunction Solar Cell under Constant Multispectral Light. 26 th European Photovoltaic Solar Energy Conference and Exhibition, 250-254.

[56] Ngom, M.I., Thiam, A., Sahin, G., El Moujtaba, M.A.O., Faye, K., Diouf, M.S. and Sissoko, G. (2015) Influence of Magnetic Field on the Capacitance of a Vertical Junction Parallel Solar Cell in Static Regime, under Multispectral Illumination. International Journal of Pure \& Applied Sciences \& Technology, 31, 65-75.

[57] Diallo, H.L., Dieng, B., Ly, I., Dione, M.M., Ndiaye, M., Lemrabott, O.H., Bako, Z.N., Wereme, A. and Sissoko, G. (2012) Determination of the Recombination and Electrical Parameters of a Vertical Multi-Junction Silicon Solar Cell. Research Journal of Applied Science, Engineering and Technology, 4, 2626-2631.

[58] Terheiden, B., Hahn, G., Fath, P. and Bucher, E. (2000) The Lamella Silicon Solar Cell. 16 th European Photovoltaic Solar Energy Conference, 1377-1380.

[59] Kopach, V.R., Kirichenko, M.V., Shramko, S.V., Zaitsev, R.V. and Bondarenko, S.A. 
(2008) New Approach to the Efficiency Increase Problem for Multi-Junction Silicon Photovoltaic Converters with Vertical Diode Cells. Functional Materials, 15, 253-258.

[60] Xing, Y., Han, P., Wang, S., Liang, P., Lou, S., Zhang, Y., Hu, S., Zhu, H., Mi, Y. and Zhao, C. (2013) Analysis of Effects of Front and Back Surface Dopants on Silicon Vertical Multi-Junction Solar Cell by 2D Numerical Simulation. Science China Technological Sciences, 56, 2798-2807. https://doi.org/10.1007/s11431-013-5378-Z

[61] Betser, Y., Ritter, D., Bahir, G., Cohen, S. and Serling, J. (1995) Measurement of the Minority Carrier Mobility in the Base of Heterojunction Bipolar Transistors Using a Magneto Transport Method. Applied Physics Letters, 67, 1883-1884. https://doi.org/10.1063/1.114364

[62] Kurnick, S.W. and Zitter, R.N. (1956) Photoconductive and Photoelectromagnetic Effects in InSb. Journal of Applied Physics, 27, 278-285. https://doi.org/10.1063/1.1722357

[63] Sze, S.M. and Ng Kwok, K. (2007) Physics of Semiconductors Devices. 3rd Edition, John Wiley and Sons, Hoboken.

[64] Lévy F. (1995) Traité des Matériaux N 18, Physique et Technologie des Semiconducteurs. Presses Polytechniques et Universitaires Romandes.

[65] Furlan, J. and Amon, S. (1985) Approximation of the Carrier Generation Rate in Illuminated Silicon. Solid-State Electronics, 28, 1241-1243. https://doi.org/10.1016/0038-1101(85)90048-6

[66] Paternoster, G., et al. (2013) Back-Contact Vertical Junction Silicon Solar Cells for Concentrating Photovoltaics. 28 th European Photovoltaic Solar Energy Conference and Exhibition, Paris, 672-675.

[67] Cuevas, A., Fossum, J.G. and Young, R.T. (1983) Influence of the Dopant Density Profile on Minority-Carrier Current in Shallow, Heavily Doped Emitters of Silicon Bipolar Devices. Solid-State Electronics, 28, 247-254. https://doi.org/10.1016/0038-1101(85)90005-X

[68] Agarwala, A. and Tewary, V.K. (1980) Response of a Silicon p-n Solar Cell to High Intensity Light. Journal of Applied Physics D: Applied Physics, 13, 1885-1898. https://doi.org/10.1088/0022-3727/13/10/018

[69] Mane, R., et al. (2017) Minority Carrier Diffusion Coefficient D*(B, T): Study in Temperature on a Silicon Solar Cell under Magnetic Field. Energy and Power Engineering, 9, 1-10. https://doi.org/10.4236/epe.2017.91001

[70] Kosso, A.M.M., Thiame, M., Traore, Y., Diatta, I., Ndiaye, M., Habiboullah, L., Ly, I. and Sissoko, G. (2018) Study of a Silicon Solar Cell under Constant Monochromatic Illumination: Influence of Both, Temperature and Magnetic Field. Journal of Scientific and Engineering Research, 5, 259-269.

[71] Diouf, S., Ndiaye, M., Thiam, N., Traore, Y., Ba, M.L., Diatta, I., Diouf, M.S., Mballo, O., Thiam, A., Ly, I. and Sissoko, G. (2019) Influence of Temperature and Frequency on Minority Carrier Diffusion Coefficient in a Silicon Solar Cell under Magnetic Field. Energy and Power Engineering, 11, 355-361.

https://doi.org/10.4236/epe.2019.1110023

[72] Berman, R. (1951) Thermal Conductivity of Dielectric Crystals: The "Umklapp" Process. Nature, 168, 277-280. https://doi.org/10.1038/168277a0

[73] Kittel, C. (1998) Physique de l'état solide. 7th Edition, 123-126. 